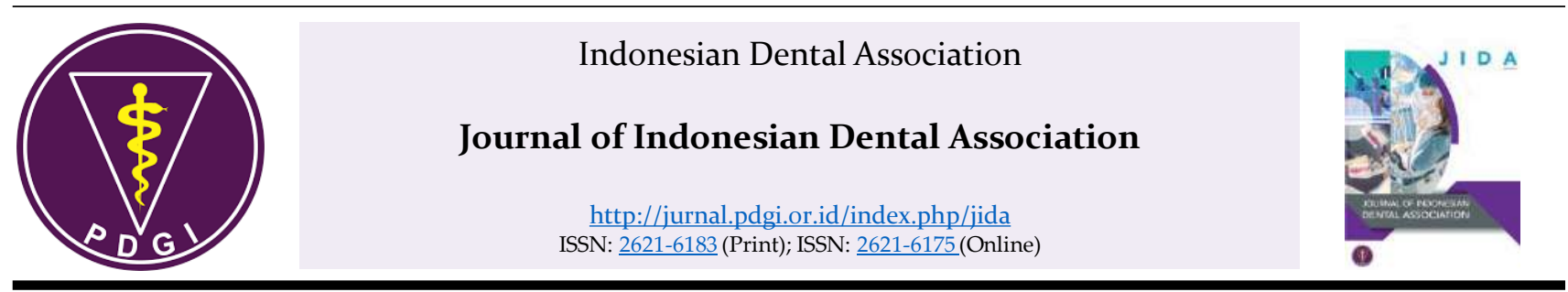

Research Article

\title{
The Impact of Academic Potential Test (APT) on GPA Score in Bachelor Dental Program in Trisakti University
}

\author{
Rahmi Amtha ${ }^{1 \S}$, Tri Erri Astoeti ${ }^{2}$, Tri Putriany Agustin ${ }^{3}$, Yohana Yusra ${ }^{4}$, Wiwiek Poedjiastoeti ${ }^{5}$, \\ Indrayadi Gunardi ${ }^{1}$
}

${ }^{1}$ Department of Oral Medicine, Faculty of Dentistry, Trisakti University, Indonesia

${ }^{2}$ Department of Public Health, Faculty of Dentistry, Trisakti University, Indonesia

${ }^{3}$ Department of Pedodontia, Faculty of Dentistry, Trisakti University, Indonesia

${ }^{4}$ Department of Orthodontics, Faculty of Dentistry, Trisakti University, Indonesia

${ }^{5}$ Department of Oral Maxillofacial Surgery, Faculty of Dentistry, Trisakti University, Indonesia

Received date: July 11, 2019. Accepted date: October 4, 2019. Published date: October 31, 2019

\section{KEYWORDS \\ academic potential test; bachelor dental program; GPA}

\begin{abstract}
Introduction: Academic potential test (APT) is the terminology used for requirement in student recruitment process at Faculty of Dentistry, Trisakti University. According to literature, APT score is believed to predict the academic achievement in graduate school. Objectives: This study assessed the impact of APT score on GPA score at Bachelor Dental Program year 2015-2018. Methods: Cross sectional descriptive analysis were done on 486 students, divided into 4 groups based on credit semester (CS); group A 144 CS, B $100 \mathrm{CS}, \mathrm{C} 60 \mathrm{CS}$, and D 20 CS. Result: mean APT score were $598 \pm 95.46$ and GPA score were $2.63 \pm 0.72$. Linear regression test showed significant correlation between APT and GPA scores $(\mathrm{p}=0.007$; $\mathrm{r}^{2}=1.5 \%$ ). It shows that APT contributed as only a little aspect for the success of students in their study. In dentistry, there are other factors that may influence GPA score beside APT such as intellectual quality, talent, behavior, psychomotor and capability in social, science and communication. Conclusion: Academic potential test could be used to predict the GPA score in Bachelor Dental Program.
\end{abstract}

\footnotetext{
$\S$ Corresponding Author

E-mail address: rahmi.amtha@gmail.com (Amtha R)
} 


\section{KATA KUNCI}

tes potensi akademik; program sarjana kedokteran gigi;

IPK

\begin{abstract}
ABSTRAK
Pendahuluan: Tes potensi akademik (TPA) adalah terminologi yang digunakan sebagai salah satu syarat dalam proses penerimaan mahasiswa baru di Fakultas Kedokteran Gigi Universitas Trisakti. Menurut literatur, nilai TPA dipercaya mampu menjadi prediksi keberhasilan akademik dalam institusi pendidikan. Tujuan: Penelitian ini akan melihat pengaruh nilai TPA terhadap nilai indeks prestasi kumulatif (IPK) pada Program Sarjana Kedokteran Gigi (SKG) pada tahun 2015-2018. Metode: Deskriptif analitis dengan rancangan potong silang dilakukan pada 486 mahasiswa, yang dibagi dalam 4 kelompok yang berbeda dalam jumlah sistem kredit semester (SKS) (kelompok A 144 sks, B 100 sks, C 60 sks, dan D 20 sks). Hasil: Rerata nilai TPA adalah $598 \pm 95,46$ dan nilai IPK sebesar 2,63 $\pm 0,72$. Uji regresi linear menunjukkan hubungan bermakna antara nilai TPA dan IPK $\left(\mathrm{p}=0,007 ; \mathrm{r}^{2}=1,5 \%\right)$. Hal ini menunjukkan bahwa TPA hanya sedikit berkontribusi terhadap keberhasilan mahasiswa dalam pendidikannya. Selain TPA, faktor yang dapat mempengaruhi nilai IPK di bidang kedokteran gigi, antara lain kualitas intelektual, bakat, tingkah laku, psikomotor dan kemampuan dalam sosial, pengetahuan dan komunikasi. Kesimpulan: TPA dapat menjadi alat untuk memprediksi nilai IPK mahasiswa Program Sarjana Kedokteran Gigi.
\end{abstract}

\section{PENDAHULUAN}

Berbagai jenis alat ukur yang dapat menilai kemampuan individu dalam bidang psikologi maupun edukasi. ${ }^{1}$ Salah satu alat ukurnya adalah tes potensi akademik, yang pertama kali dibuat pada tahun 1949 dengan istilah "graduate record examination (GRE)", merupakan alat ukur terstandarisasi untuk mengukur kemampuan siswa. ${ }^{2}$ Tes ini pertama kali diciptakan oleh educational testing service tahun 1939 untuk mengukur penguasaan verbal, penguasaan kuantitatif, penulisan analitik dan keterampilan berpikir kritis yang dicapai oleh siswa melalui proses pembelajaran jangka panjang. ${ }^{3}$ Berbagai laporan ilmiah menunjukkan korelasi yang bervariasi antara tes potensi akademik (TPA) dan nilai pendidikan dalam berbagai program akademik. ${ }^{2,4}$ Dalam Fakultas Kedokteran Gigi Universitas Trisakti, seluruh mahasiswa yang akan masuk mengikuti pendidikan, wajib melakukan tes potensi akademik dan tes tersebut dipercaya mampu memprediksi keberhasilan akademik. Tes potensi mampu mengukur kemampuan kognitif umum yang dirancang untuk melihat kemungkinan keberhasilan pendidikan di perguruan tinggi. 5,6,7 Pada tes potensi akademik di Universitas Trisakti, pelaksanaannya mengukur tiga jenis aspek yaitu kemampuan bahasa (verbal), kuantitatif dan pengetahuan umum (penalaran).

Hasil meta-analisis yang dilakukan pada tahun 1995 oleh Morrison T dan Morrison M, menunjukkan bahwa penggunaan GRE sepertinya tidak dapat dijadikan acuan tunggal untuk prediksi keberhasilan siswa, terlebih lagi jika GRE dikelompokkan berdasarkan usia, jenis kelamin dan ras. ${ }^{2}$ Umumnya, tes potensi akademik tidak disusun berdasar silabus mata pelajaran. Oleh karena itu, keberhasilan menjawab butir soal pada TPA tidak berkaitan dengan penguasaan mata pelajaran tertentu. Soal dalam TPA, dikembangkan pada daya penalaran (reasoning) secara logis maupun analitis. ${ }^{8}$ Oleh karena terdapat asumsi bahwa tes potensi akademik dapat mengukur kemampuan penalaran kognitif umum mahasiswa dalam pendidikan tinggi, maka hal ini menjadi alasan utama bahwa tes ini dapat digunakan sebagai salah satu pertimbangan dalam seleksi masuk selain indikator keberhasilan lain, seperti tes matematika, kimia dan fisika serta bahasa Inggris. ${ }^{9}$ Hasil meta-analisis Kuncel dkk menunjukkan bahwa GRE berperan sebagai prediktor yang bermakna dalam menentukan nilai indeks prestasi kumulatif (IPK) mahasiswa sarjana dari berbagai bidang disiplin ilmu. ${ }^{10}$ Penelitian ini bertujuan untuk mengetahui pengaruh tes potensi akademik terhadap pencapaian nilai pendidikan yang diukur menggunakan indek prestasi kumulatif dari mahasiswa program sarjana kedokteran gigi Fakultas Kedokteran Gigi Universitas Trisakti.

\section{BAHAN DAN METODE}

Penelitian deskriptif analitik dengan rancangan potong silang yang diambil dari data TPA dan IPK mahasiswa program Sarjana Kedokteran Gigi dari empat periode tahun 2015 sampai dengan 2018. Pemilihan subjek berdasarkan data sekunder yang paling lengkap dalam sistem tiap periode. Empat periode dikelompokkan menjadi kelompok A yaitu mahasiswa periode tahun 2015 sebanyak 88 subyek yang telah menyelesaikan 144 sks (sistem kredit semester); kelompok B yaitu mahasiswa periode tahun 2016 sebanyak 82 subjek yang telah menyelesaikan 100 sks, kelompok C yaitu mahasiswa periode tahun 2015 sebanyak 151 subjek yang telah menyelesaikan 60 sks; dan kelompok D yaitu mahasiswa periode tahun 2015 sebanyak 165 subjek yang telah menyelesaikan 20 sks. Tes TPA dilakukan pada tahun pertama saat subjek masuk sebagai mahasiswa. 


\section{Analisis Statistik}

Data dianalisis menggunakan regresi linier dengan korelasi bermakna sebesar $<0,05$.

\section{HASIL}

Total sebanyak 486 subjek disertakan dalam data penelitian. Nilai TPA di Dari seluruh kelompok, rerata TPA sebesar 598,04 $\pm 95,46$ dan rerata IPK sebesar $2,63 \pm 0,72$. Regresi linear menunjukkan bahwa seluruh kelompok mempunyai korelasi bermakna antara TPA dan IPK dengan $\mathrm{p}=0,007, \mathrm{r}^{2}=1,5 \%$ (Gambar 1). Dalam scatter plot, nampak distribusi variabel dengan pengelompokan subjek dalam positif linearitas sebagai berikut IPK $=0,024+0,06804 \quad$ (TPA). TPA sebagai faktor independen dapat memprediksi nilai IPK sebesar 1,5\%.

\section{PEMBAHASAN}

Tabel 1 menunjukkan bahwa ada korelasi yang bermakna antara TPA dan IPK dari seluruh kelompok. Kelompok A dan B paling berkorelasi dibandingkan kelompok C dan D. Kelompok A memiliki rerata TPA lebih rendah daripada kelompok lainnya, meskipun jumlah sks yang telah dicapai adalah paling tinggi. Besar jumlah sks yang diambil, tidak berkorelasi dengan kedua variabel baik TPA maupun IPK yang dicapai. Perbedaan antara nilai dan jumlah sks dari tiap kelompok, dihitung berdasarkan konstanta antara nilai IPK dengan jumlah sks. Setelah konstanta didapatkan, maka baru dapat dibandingkan antara tiap kelompok. Oleh karena konstanta yang dihasilkan tiap kelompok berbeda, hal ini menyebabkan nilai TPA dapat sama tinggi tetapi hasil IPK mungkin berbeda. Hal ini juga menggambarkan bahwa ada faktor lain selain TPA untuk memprediksi IPK.

Berdasarkan gambar 2A sampai D (plot P-P normal), menunjukkan penyebaran data IPK subjek per kelompok tersebar mendekati garis tengah. Pada Gambar 2A, menunjukkan sebaran data yang agak menjauhi garis tengah. Hal ini dapat diperjelas pada Gambar 2B yang menunjukkan sebaran data seluruh kelompok antara nilai TPA dan IPK yang dibagi oleh jumlah sks. Apabila analisis dilakukan pada seluruh kelompok, maka $\mathrm{r}^{2}$ dari masing-masing kelompok akan menjadi 0,015, yang berarti TPA hanya berperan sebesar $1,5 \%$ dalam pencapaian IPK. TPA benar dapat membantu untuk mengukur tingkat kognitif dari mahasiswa program SKG bidang kedokteran gigi, tetapi perlu mempertimbangkan faktor-faktor lain seperti kualitas intelektual, bakat, sikap, psikomotor dan kemampuan sosial, pengetahuan dan komunikasi. ${ }^{11}$

Sesuai dengan Standar Kompetensi Dokter Gigi Indonesia tahun 2015, pendidikan kedokteran gigi terdiri dari ilmu pendidikan dasar kedokteran, kedokteran gigi untuk teori dan keterampilan. Pendidikan keterampilan ini tidak berhubungan secara linier terhadap tingkat kognitif dari mahasiswa. ${ }^{12}$ Hal ini didukung dari laporan Grillo dkk ${ }^{13}$ yang menyatakan bahwa TPA untuk Program Sarjana Kedokteran Gigi (SKG) memiliki tingkat bervariasi antara setiap mahasiswa. Dalam penelitian penulis, TPA dapat mempengaruhi IPK, tetapi hanya berperan dalam pendidikan program SKG saja, yaitu pendidikan teori, bukan pendidikan profesi (yang menilai gabungan aspek kognitif, psikomotor dan afektif secara bersamaan, seperti pada penilaian direct observation of procedural skills/DOPS). Pada program pendidikan yang menekankan pada kemampuan kognitif, skor TPA cenderung berperan dalam memprediksi kemampuan verbal, kuantitatif dan analisis dari mahasiswa. ${ }^{10}$ Bidang ilmu kedokteran gigi, menyerupai bidang ilmu kedokteran yang lebih banyak menggali kemampuan verbal (padanan kata, lawan kata, analogi kata), analisis (penalaran logis, penalaran diagram, penalaran simbol dan penalaran analitis) dan sebagian kecil mengenai psikomotor. Kemampuan kuantitatif yang terdiri dari deretan angka, aritmatika, konsep aljabar dan geometrika, kurang ditekankan pada program pendidikan kedokteran gigi. Hasil penelitian ini sama dengan berbagai kajian ilmiah dan meta-analisis peneliti sebelumnya. ${ }^{2,8,14,15}$

A
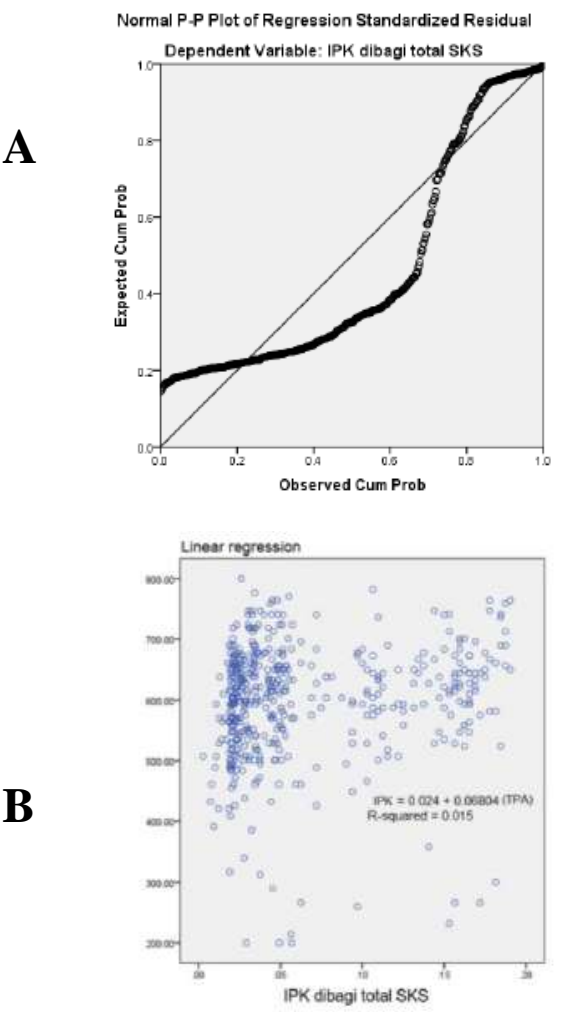

Gambar 1. A. Plot P-P normal regresi linear antara TPA dan IPK untuk seluruh kelompok. B. Scatter plot dari nilai tes potensi akademik dengan nilai IPK yang dibagi total SKS. 
Tabel 1. Regresi linier dari masing-masing kelompok antara variabel TPA dan IPK.

\begin{tabular}{ccccccc}
\hline \multirow{2}{*}{ Kelompok } & \multirow{2}{*}{$\mathbf{n}$} & \multirow{2}{*}{ SKS } & \multicolumn{2}{c}{ Rerata \pm SD } & \multirow{2}{*}{$\mathbf{r}^{2}$} & p \\
\cline { 4 - 5 } & & & TPA & IPK & & \\
\hline A (2015) & 88 & 144 & $587,01 \pm 75,67$ & $3,07 \pm 0,24$ & 0,137 & $0,000^{*}$ \\
B (2016) & 82 & 100 & $605,29 \pm 82,48$ & $2,64 \pm 0,65$ & 0,245 & $0,000^{*}$ \\
C (2017) & 151 & 60 & $595,54 \pm 106,49$ & $2,45 \pm 0,70$ & 0,03 & $0,032^{*}$ \\
D (2018) & 165 & 20 & $602,60 \pm 100,31$ & $2,56 \pm 0,84$ & 0,051 & $0,002^{*}$ \\
\hline
\end{tabular}

SKS sistem kredit semester, TPA tes potensi akademik, IPK indeks prestasi kumulatif $* \mathrm{p}<0,05$
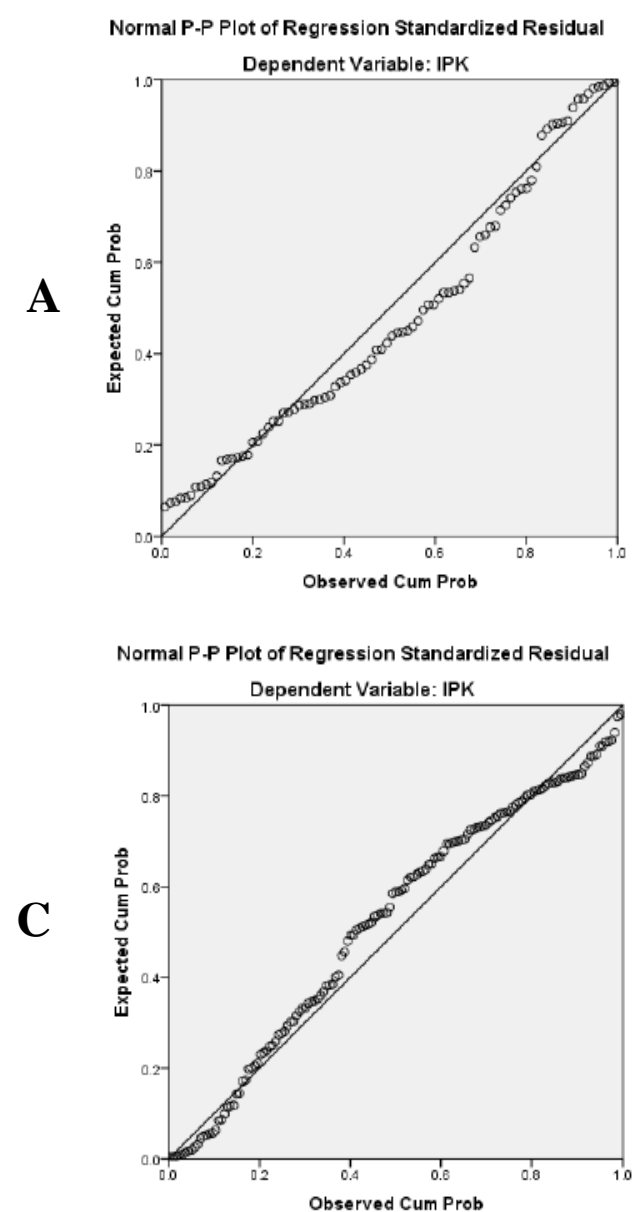
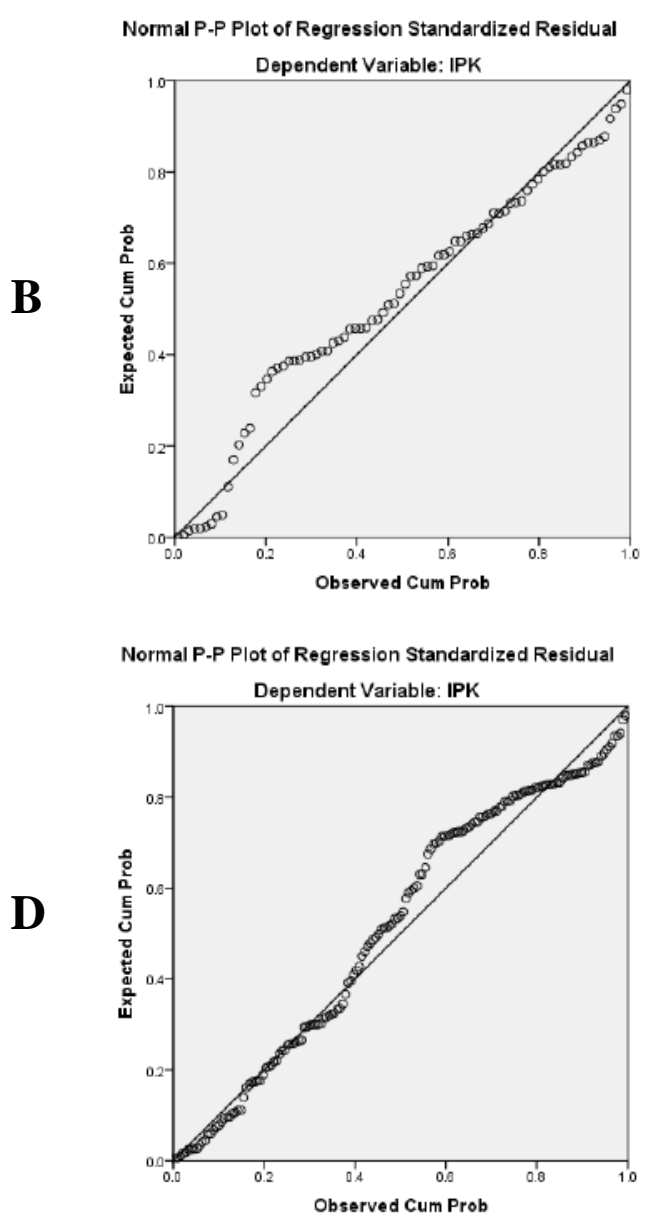

Gambar 2. Regresi linear antara TPA dan IPK pada kelompok A, B, C dan D

Pada penelitian lain, kesuksesan mahasiswa kedokteran dapat diprediksi menggunakan alat ukur yang disebut HAM-Net (Hamburger Auswahlverfahren für medizinische Studiengänge atau natural science knowledge test), yang terdiri dari beberapa komponen kemampuan kognitif, kemampuan analisis atau intelektual. ${ }^{16}$ Hasilnya menunjukkan bahwa alat ukur yang digunakan dapat menjadi prediktor kesuksesan dalam edukasi dan pekerjaan. Namun penggunaan alat ukur tersebut dalam bidang pendidikan kedokteran ${ }^{17}$, kemampuan kognitif lebih banyak dipengaruhi oleh berbagai faktor disamping kognitif, yaitu karakter bawaan personal seperti motivasi pencapaian, kesadaran diri untuk belajar dan kestabilan emosional. ${ }^{18,19}$ Jadi pada penelitian Meyer $\mathrm{dkk}^{16}$, dengan menggunakan HAM-Net, dapat menyaring siswa dengan kemampuan akademik yang baik pada periode sekolah menengah atas dan dapat memprediksi siswa tersebut melewati kurikulum tahun 
pertama di kedokteran dengan baik. Pada program SKG, selain TPA perlu dipertimbangkan penggunaan alat ukur yang terstruktur dengan validitas kontruksi soal uji yang valid. Artinya, setiap butir soal telah dianalisis item measure-nya secara benar dan reliabel.

\section{KESIMPULAN}

Tes potensi akademik dapat direkomendasikan dan digunakan untuk memprediksi nilai indeks prestasi kumulatif dalam program Sarjana Kedokteran Gigi. Namun, masih banyak faktor lain yang berperan dalam penentuan nilai IPK dan keberhasilan mahasiswa dalam menempuh ke program profesi Kedokteran Gigi.

\section{KONFLIK KEPENTINGAN}

Penulis menyatakan tidak terdapat konflik kepentingan yang berkaitan dengan manuskrip ini.

\section{DAFTAR PUSTAKA}

1. Thorndike RM, Cunningham GK, Thorndike RL, Hagen EP. Measurement and evaluation in psychology and education. New York (NY): Macmillan Publishing Company; 1991.

2. Morrison T, Morrison M. A meta-analytic assessment of the predictive validity of the quantitative and verbal components of the graduate record examination with graduate grade point average reprensiting the criterion of graduate success. Educ Psychol Measure 1995;55(2):309-16.

3. ETS. GRE: Guide to the use of scores 2019-20. 2019. https://www.ets.org/gre/guide

4. Weiner OD. How should we be selecting our graduate students? Mol Biol Cell. 2014;25:429-30.

5. Borg WR. GRE aptitude scores as predictors of GPA for graduate students in education. Educational and Psychological Measurement. 1963;23:379-382.

6. Hebert DJ, Holmes AF. Graduate record examinations aptitude test scores as a predictor of graduate grade point average. Educational and Psychological Measurement. 1979;39:415-420.

7. Bell SM, Blumstein J, Brose K, Carroll A, Chang J, Charles J, et al. Defining success in graduate school. Mol Biol Cell. 2014; 25(13):1942 \pm 1944.

8. Azwar S. The quality of the tes potensi akademik
(TPA) 07A. J Penelitian dan Evaluasi Pendidikan. 2008;12(2):231-50.

9. Ingram RE. The GRE in the graduate admissions process: Is how it is used justified by the evidence of its validity? Professional Psychology Research and Practice. 1983;14:711-714.

10. Kuncel NR, Hezlett SA, Ones DS. A comprehensive meta-analysis of the predictive validity of the graduate record examinations: implications for graduate student selection and performance. Psychological Bull. 2001;127(1):162-81.

11. Miller C, Stassun K. Careers: a test that fails. Nature. 2014:510:303-4.

12. Kuncel NR, Wee S, Serafin L, Hezlett SA. The validity of the Graduate Record Examination for master's and doctoral programs: a meta-analytic investigation. Educ Psychol Meas. 2010;70:340 \pm 352 .

13. Grillo AC, Ghoneima AAM, Garetto LP, Bhamidipalli SS, Stewart KT. Predictors of orthodontic residency performance: An assessment of scholastic and demographic selection parameters. Angle Orthod. 2019;89(3):488-494.

14. Burton NW, Wang M. Predicting long-term success in graduate school: a collaborative validity study. GRE Board Report No. 99 $\pm 14 R$, ETS RR-05-03. Princeton (NJ): Educational Testing Service; 2005.

15. Moneta-Koehler L, Brown AM, Petrie KA, Evans BJ, Chalkley R. The limitations of the GRE in predicting success in biomedical graduate school. PLoS One. 2017;12(1):e0166742.

16. Meyer H, Zimmermann S, Hissbach J, Klusmann D, Hampe W. Selection and academic success of medical students in Hamburg, Germany. BMC Med Educ. 2019;19(23):1-15.

17. McManus IC, Dewberry C, Nicholson S, Dowell JS, Woolf K, Potts HWW. Construct-level predictive validity of educational attainment and intellectual aptitude tests in medical student selection: metaregression of six UK longitudinal studies. BMC Med. 2013;11:243.

18. Higgins DM, Peterson JB, Pihl RO, Lee AG. Prefrontal cognitive ability, intelligence, big five personality, and the prediction of advanced academic and workplace performance. J Pers Soc Psychol. 2007;93(2):298-319.

19. Duckworth AL, Seligman MEP. Self-discipline outdoes IQ in predicting academic performance of adolescents. Psychol Sci. 2005;16(12):939-944. 